\title{
$\mathbf{x}$
}

\section{NOTES ON THE LANGUAGE OF THE DVAVIMSATYAVADANAKATHA}

\author{
BY R. L. TURNER
}

THE Dvāvimśatyavadānakatha is a compilation of
Buddhist Birth-stories of comparatively late origin. Much of it, particularly of the prose portions, was borrowed from the Avadanaśataka at a time when the MSS. of that work were already faulty. The recension of the Avadanasataka, from which the author of the Dvă. took his material, was that to which Speyer's MS. D belonged. The language in which it is written resembles that of most of the Northern Buddhist texts, in particular the Vicitrakarnikāvadāna-that is to say, a kind of popularly developed Sanskrit, which shows for the most part the same line of growth as that followed by the Prākrit dialects many centuries before. The solution of the history of this dialect, and of the question whether, as is probable, it was only a written language, depends on the collection of more material. Below I give a detailed list of the points in which the Sanskrit of the Dvan. differs from classical Sanskrit both in forms, in syntax, and vocabulary. It is possible that scribal errors may be responsible for some of the forms. Few of them are invariable; most are found side by side with their classical equivalents. It will be seen that the majority of the forms and constructions can be paralleled from Pãli and the Prākrits. The figures placed in brackets after forms show the number of times they occur in the text. 


\section{Phonology}

1. Orthography.-None of the MSS. are probably older than the eighteenth century. All interior nasals are usually written with $m$; preconsonantal $-m$ is seldom assimilated; $-n$ of the loc. sing. of pronouns is usually written -m, e.g. tasmim ; -tva- for -ttva-, e.g. satva chitva for sattva chittvā; -jva- for -jjva-, e.g. ujvala rajvā for ujjvala rajjvā; any consonant after $r$ is doubled, e.g. dharmma antarddhapita samtarppita; there is no distinction made between $u$ and $\bar{u}, b$ and $v$, st and sth; there is occasional confusion between $v$ and $b h$, st and $s t h$, $s$ and $l h, s$ and $s, r$ and $l$.

2. Sandhi.-The sandhi of consonants is for the most part regular. In nine cases the forms are left unaltered : -t $m-$, , $a n a_{-},-t c-,-t p-,-t b h_{-},-t s_{-},-t a-$; while final $-s$ is eighteen times treated irregularly: -as $a->-a a-(10)$, $-s k$ - > -ok- (2), -as p->-op-, -ass->-os-(2), -us $a$ - >-uh $\alpha$-, $-a s c->-a h c-$, and $-\bar{a} r->-\hat{a} r-(2)$. Double sandhi occurs fifteen times: $-a s u->-\hat{o}-(2),-a s e->-\hat{a} i-(3),-\bar{a} s a->-\hat{a}-(3)$, $-\bar{a} s \quad \bar{a}->-\hat{a}-,-\bar{\imath} s i->-\hat{\imath}-,-e \quad a->-\hat{a}-,-e \quad i->-\hat{e}-(2),-e \quad e->-\hat{a} i-$, $-a u u->-\hat{a} u-$. The cases in which sandhi takes place and those in which hiatus is left are in the proportion of $7: 2$, reduced in the case where the final vowel is $\bar{a}$ or $\bar{\imath}$ to $1: 4$. The oldest MS. occasionally has -ar $a$ - from -as $a-$. The sandhi consonant $m$ is used nine times: e.g. nirdisyam iti for nirdiśyêti, ābhogah karañỹam iti for karañyya iti.

3. Prosody - - am, though followed by a consonant, is short; the examples are $(a)$ in the fifth syllable of the śloka (15), (b) in the thirteenth (12), of which nine rest upon conjecture, $(c)$ in the sixth syllable of indravajra (conjecture). -ah, though followed by a consonant, is short (2). A short final vowel, whether of a single word or of a member of a compound, remains short before two consonants: before $j \tilde{n}(2), d v, p r(2), v y, s r(3), s n .-a m$ is elided before a vowel (4); - am is long before a vowel (2). aya and ava are scanned as one long. 


\section{MORPHOLOGY}

Nouns

1. Declension.—a-stems : nom.p.n. in a, e.g. karmāni - suikurā, ratnāni ca samāhulāa (end of a śloka) (8); ab.p. -ehi in nârakehi; some adjectives form the feminine in $-\bar{a}$ instead of $-\bar{\imath}$, e.g. $v r k \bar{a}$ for $v r k \bar{\imath},-m u k h \bar{a}$ for $-m u k h \bar{\imath}$.

$i$-stems: acc.p.f. -ayas in dundubhayah ; n.s.n. -iṇ in udapānakāadin.

$u$-stems: nom.s.n. -um in bahum, ripum.

$r$-stems: acc.s.m. $-\bar{a} m$ in $b h a r t t \bar{\alpha} m$.

$j$-stems : nom.s.m. $-r \bar{a} t$ from $-r \bar{a} j(3)$.

s-stems : loc.p. -usu in vapusu.

in-stems: nom.s.m. -is in apalēarih aparādhit. caliravarttih sresthith, $-\bar{\imath} s$ in cakravarttīh; nom.s.f. $-\bar{\imath}$ in kesi $v \bar{\alpha} s \bar{\imath}$ vistāi $\bar{\imath}$ vrat $\bar{\imath}$.

at-stems: nom.s.m. -antas in kirttivantah; nom.s.n. -antam in mahäntam sarvāvantam; voc.s.m. -ān in bhavān (2).

yas-stems: nom.s.n. -yasam in garīyasam śreyasam.

an-stems : nom.s.n. -am in karmmaṇ nāmam premaṇ ; nom.p.m. -anas in -ātmanah.

2. Gender.-a-stems: n. for m. anuräga amoda artha $\vec{a}$ rambha äräma utpāta utsāha udaya (2) udbhava udyoga upasamhiāra ullola käla kośa guna candra dharma (2) parvata prōna bhoga molṣa (2) moda rasa läbha (2) lobha varșa (3) sara soka samsāara (3) samskīāra (2) sañcaya sañcāra satkāra (2) samaya (2) samudaya sambhava stūpa (4) svāda; m. for n. naksatra yojana vañcana samkata; m. for f. pravrajya prāsādika mary-

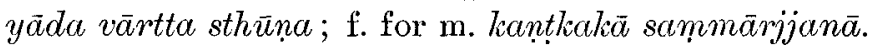

i-stems: $\mathrm{m}$. for f. dēpti prakrti rātri; n. for $\mathrm{f}$. drsti (2).

$u$-stems : f. for m. dhātu (3); n. for m. ripu.

an-stems: m. for n. parvas for parva.

3. Formation of Stem.-New forms without alteration of meaning are made by the use of additional suffixes: $-a$, JRAS. 1913. 
arcisa cetasa (2) -chida? patnyō (for patnī) parşada mandalina rogina vanïa (7) vāca (3); -ka, aparāadhaka arthalka avatamsalia avadānalka (2) asāralka rddhika ekika kațka gämika cāturdvīpaka cittaka tulyaka pakṣika pragalbhika mānușikī mārgaka vastuka samsārilia ; -tva, lisayatva manusyatva; -na, adhivāsana; -ya, bhaiksya vinodya dhairyya; -in, kaștin sanımukhin; -bhüta, manusyabhüta varşabhüta svacchabhüta hetubhītce (2).

The vrddhied form is used in the same sense as the simple: kauśala cãturdvīpaka jānapada tāthāgata (2) däridra (2) dhairya bauddha (5) brähman bhaikșuka mānusya māndärava laukika vāeas (2) sāmartha.

\section{Pronouns}

tam for tad (3), imaṇ for idam (3), yam for yad, ayam and $i m \bar{a}$ for iyam. The loc.s.m. and n. is usually written -im.

Numercals

catvara-for catur-,träyatrimśa "30", trayahseta "300".

Adverbs

atre, paratre for -tra, tatas, "there"; idam, "hither"; tasmim, "here."

$$
\text { Particles }
$$

$p i$ for api.

\section{Verbs}

1. Formation of Present Stem.--Simple: jvālat:jval, dadati(2) dadanti dada pradadasva : da, avadhīryyatha: ? dhr, bhindanti: bhid, nivāsata : vas, visksambhamānam: skambh, krameyam samkrameyam upasamkrameyam: kram, prabudhyati:budh. Causative: adhiryyayati: adhi r, kārāpayitavyāh,: lir, pratinivrttayati: vret, samuttejayati:tij, vaijayanti:vij. Desiderative: jijñ $\bar{a}-$ sayeyam, mīmāmsayeyam. Denominative: guptayan, "hide"; ārāgayeyam, "love"; virāgayeyam, "dislike."

2. Finite Forms.-Imperfect, unaugmented forms: caran prakrämat. Imperative: 2 p. avadhīryyatha 
śrnotha (2). Optative: pradeyuh from dā. Future: raksyati for raksisyati. Perfect: dadarśur, cakārayām $\bar{a} s u \hbar$, , paramaprusāadayām $\bar{a} s a$, vidadhāmata, 3 p. perfect, from $d h \bar{a}$. Aorist : aśroṣit always for aśrausīt. Precative: bhūyām for $b h \bar{u} y \bar{a} s a m$. The passive has active terminations: bhidyati parimucyemah pratapyati.

3. Infinite Forms.-Indeclinable part.: praśāntya from sam; in -ya with the simple root, krtya grhya cintya (3) smrtya; in $-t v \bar{a}$ with the compounded root, abhivanditv $\bar{a}$ prativanditvā. Pres. part. : jñ $\bar{a} n a n$ from $j \tilde{n} \bar{\alpha}$. Gerundive :

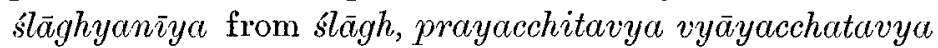
from yam. Past part. pass.: prechita (2) from prach; bhagnita from bhañj, apaharita praharita from $h \varphi^{2}$. The infinitive of causatives ends in -itum : darsitum mänitum pratinivertitum.

\section{Composition}

1. The first member is formed by nom.p.n. (3), e.g. karanāniksayo bhavisyatîti; by sa- (3), e.g. sarājadrstamätrena - - subhāygā bhavanti, "their limbs were made clean just at the sight of the king"; by $s \bar{a}-(2)$, e.g. sāpānapradāyikāadevakanyāyā etad abhavat, "this occurred to the divine maiden who had made a present of drink" ; by saisa-, saișalsapotam tulayitva, "weighing this dove"; by kaścid- (4), e.g. tatah kaścidvarșāntare gate $s \bar{a}-$-, "then an interval of some years having passed she - -"; by kiñcid-, kiñcitkāryyakarmmāni, "some duties"; by a feminine adjective in $-\bar{\alpha}$ or $-\bar{\imath}$ (5), e.g.

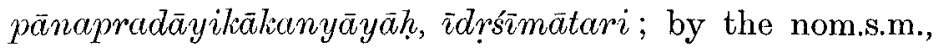
saräjädrstamātrence, bhrātäviyoge, "separation from his brother"; Vapusmānavadānakam, "the avadāna of Vapuṣmat."

2. The last member is formed by iti, Ratnamatitikhy $\bar{\alpha}-$ tavān, "named Ratnamati"; by -rājo $\bar{\alpha}$, mandalinarāj $\bar{\alpha}$, "petty chieftain"; by upari, simhasanopari, "on the throne"; by a numeral, anyatamōstau, " 8." Final -as becomes -a, prabhātamana varjitamana Suddhaceta. 


\section{LANGUAGE OF THE DVAVIMSATYAVADANAKATHA}

3. The instrumental of $s a$ - ("with") compounds is used instead of the inst. of the simple noun (4), e.g. sasamghena for samghena or sasamghah. Cf. the use of sílayuktena for sillayultah, dayāyuktaih for dayāyuktah, and, lastly, ksayitasakalusah for ksayitalealuṣah.

4. Split compounds are common, e.g. sarvair gunnalamkrtah, " adorned with all virtues."

5. Copulative compounds.-(a) Form: Brahmendrarudram for -rudrāh.

(b) Adjectival copulatives are freely used (17), e.g. püjyamānyābhivandya, "to be revered, honoured, and esteemed"; praśāntakalikalahadimbadambarataskararogāpagataśālīkṣugomahișisampannam nagaraṃ, "a city free from fighting, brawling, strife, and quarrels, without diseases or robbers, provided with rice and sugar-canes, cows, and buffaloes."

6. Dependent compounds.-(a) The qualifying member comes second: (i) e.g. pādakhañja, "a lame foot"; putrasahasraih, "with a thousand sons," etc. (10); (ii) in personal names (28), e.g. Sautirnavanijah, "the merchant Sautirṇa"; Ksemamkarasamyalsambuddhasya, "the perfect Buddha Kṣemamkara."

(b) The compound is used to express accompanying circumstances: (i) in the instrumental (11), e.g. $s a-$ prasādajātena--prakrāntah, "he went forth with joy born in him"; (ii) in the locative (4), e.g. snatva ca prasādo bhavati prasādajāte tathē karisyati, "having heard, joy arises in him; when joy arises, he will do thus." Compare the frequent use of the neuter adjective as a noun.

7. Descriptive compounds.- ( $a$ ) The qualifying member comes second (23), e.g. prasādajāta, "having joy born in one"; parārthakrta, "having performed a favour for another."

(b) (i) The masc. sing. of a dependent descriptive is 
equivalent to a noun (6), e.g. vikalendriyah $=$ vikalendriyāni $i$; kusthāvistaśarīrakah, "a leprous body"; (ii) (e)tad as the first member means "this" (2), e.g. etatsamksepatah, "from this summary."

\section{SynTAX}

\section{Nouns}

1. Cases.-Accusative: (a) adverbial (4), e.g. $s a$ prthivim akantam--adhyassayati, "he rules the earth with mercy"; (b) of respect, expressing a more or less vague connection with the subject (8), e.g. $s a-n \bar{a} v a m$ bhagn $\bar{\imath} b h \bar{u} t v \bar{a}-\mathrm{k} \bar{a}$ lam gatah, "being shipwrecked he died"; athâpi na kaścit paritrănam bhavati, "then there was no one to help"; (o) governed by a noun (common), e.g. Bhagavantam arcanārtham, "to do honour to Bhagavat"; rohanāc campakam puspam, "from the growth of the campaka flower."

Instrumental : $(\alpha)=$ ablative, e.g. vyutthãya samādhin $\bar{\alpha}$, "standing up out of his trance"; tadā kenâpi kathyamänena śrutam, "it was heard from one speaking." (b) = the locative (2), e.g. pitur vācah sirasa nidha $y a$, "placing his father's commands on his head."

Ablative: this case is common with saha-compounds in the sense "as soon as", e.g. sahadarśanāc ca Bhagavatah. pādābhivandanam krtvā, "worshipping Bhagavat's feet as soon as he saw him."

Genitive = dative after verbs of saying (common), e.g. Bhagavān tasyditad avocat, "Bhagavat said to him."

Locative: $(a)=$ dative after verbs of saying, etc. (7), e.g. tvayi ucyatam, "let it be told to thee"; rājo tvayi nimantranam presitah, "the king has sent you an invitation"; $(b)=$ the ablative (4), e.g. kath $\bar{a} m$ - - śrutā $m$ me mätari kvacit, "a tale once heard by me from my mother"; Tathāgate - vyākaranam pratilabheyam, "may I receive a prophecy from the Tathägata."

2. Number-(a) The plural is used in place of the dual (2), e.g. asmākam for āvayoh. 
(b) The plural of abstract words is used instead of the singular (6), e.g. sthitih prthivyāh khalu eva satyaith, "the earth stands by truth"; jñ̄anair vithīnah, "bereft of knowledge."

(c) The plural of instrumentals of manner is used instead of the singular (8), e.g. sādaraith visesait for sādarena viśsesena.

(d) Concord is neglected (2), e.g. kasmaicid bhiksararthikebhyo dānam dātum icchāmi, "I wish to give a gift to some people needing alms."

3. Gender.--(a) Concord is neglected (5), e.g. vrksam utthito gatah, "the tree rose up and walked"; striyau sthitau, "two women were there."

(b) The neuter of the adjective is used as a noun (48), e.g. svena ca gunalabdhāya, "in order to gain virtue for

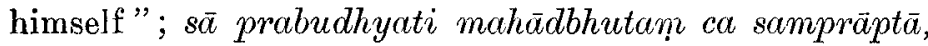
"she awoke and fell into great astonishment"; vivaśatt, "because of independence"; punar api tasyāh kosthāgāre

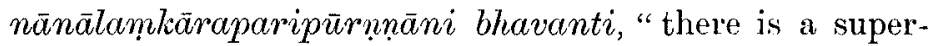
fluity of ornaments in her chamber."

\section{Pronouns}

1. nau, me, vo are used as the first word in a sentence.

2. The relative is attracted to the case of the correlative, and the correlative is omitted (3), e.g. yeșam unnatacittānām mānadarppamadaprahānārtham parșadbhyo dharmmañ deśitavān =ya unnatacittās tesānn - - ; yeșām annavihīnānām sarvadharmmaṇ vișīdati=ye 'nnavihīnās tesăàm - - -.

\section{Particles}

uta =and, e.g. Brahmä sahämpatih. Ślkro devendra uta catvāro lokapātāh.

$c a:(a)$ is placed between the two words or phrases

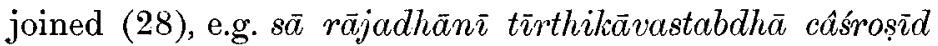

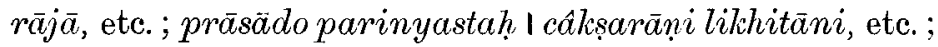

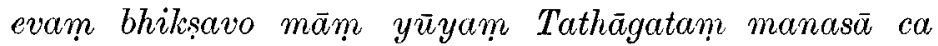


vādena samudacaritavyam. (b) It connects the members of a copulative compound (6), e.g. atha khalu - abhirūpadarśañyaprāsādikam ca drștva Bhagavantam. evam ücuh; sarvam hi artham aticañcalablearguran! ca (vasuntatilake metre). (c) It is a slightly emphatic particle or a mere expletive (48), e.g. evam ulete 'tha Bhagavāl lokānām vismayāya ca I nimittam naikam akarot tāsñin bhütvâtra tisthati $\|$ and kusalaṇ tava rōjjendra bāhyābhyantaram eva ca.

$m \bar{a}=n a$, e.g. siddhāni savvakāryyāni mā kaścidrujaȳ vapuh, "all his duties are performed; his body is not afflicted by any disease."

$v \bar{a}=e v a(2)$, e.g. kasmai sädhayate dravyam putro vā te na vidyate, "for whom is thy wealth being prepared? thou hast no son."

$v \bar{a}-v \hat{a} t h a v a i=v \bar{a}-v \bar{a}$, e.g. bharttā me 'pi mrto vâpi jivito vatha vā punah, "whether my husband is dead or is alive."

\section{Verb}

1. Tenses and Moods.-Present: (a) 2 s.=imp. 2 s.,

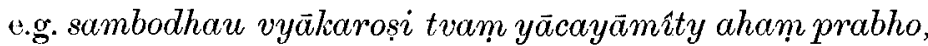
"do thou prophesy the complete enlightenment: thus I beseech thee, lord." (b) 2 p. = imp. 2 p. (3), e.g. bhits-

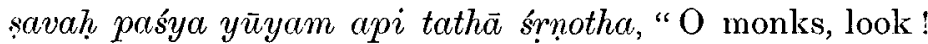
do ye also listen thus." (c) $3 \mathrm{s.}=$ imp. 3 s., e.g. me rakṣa janalka kascid a gacchati tvadīritah, "protect me, father ; let one come sent by thee." (d) $m \bar{a}$ with the $2 \mathrm{~s}$. is used for prohibition (3), e.g. mā vadasîdrśam vācam mā krodham sahasā vraja, "speak not thus; become not suddenly wroth "; tistha $m \bar{\alpha}$ bhittasi, "stay, be not afraid."

Imp. : (a) 2 s. $=2$ p. (14), e.g. śrnuṣva blikșupumgavāh, bhikșavaḷ paśya yūyam api tathā șrnotha. (b) 3 s. = 2 s. (8), e.g. tath $\bar{a}$ tvarn samudramadhye pañcatvam upagacchatu, "so mayest thou die in the middle of the sea"; tāta tebhyah parìtāni dadätu, "father, give them the pieces." (c) 3 p. $=2$ p. pres., e.g. lssipram paläyata yadi 
na palāyata naśyata, "go quickly; if you do not go you will perish."

Optative: $m \bar{a}$ is the negative (frequent), e.g. tasmāt kiārañan mà khedam kārayet pitarāv api, "therefore let a man not distress his parents"; mancsapi ma cintayet, "let a man not think in his heart."

Future: (a) 2 s. $=2$ s. imp., e.g. svapnam dāsyasi me nätha asti nâsty atha vā mune, "give me a dream, lord, to say whether he lives or not." (b) $m \bar{a}$ with the 3 p. is used for prohibition, e.g. vō mā anarthan karisyanti, "let them do you no harm." $(c)=$ the optative, e.g. bhiksavo yadi mriyadhvam tathâpi na yusmabhyam dadāmy api pänīyam ghațo me ūno bhavisyati, ". . my jar would not be sufficient."

2. Participles.--Past participle passive: $(a)$ is used actively with all verbs (54), while the participle in -tavat is used actively only about twenty times. e.g. tathaivanyalokâpy uktāh, "thus other people spoke"; iti cintitah, "thus he thought"; sa punar api drstah, "he saw again." The auxiliary $a b h \bar{u} t$ is frequently added, e.g. șatpāramitāh pratilabdho 'bhüt, "he received the ten perfections"; vihāram kārito 'bhüt, "he had a hall built." The following participles are thus used actively: antarddhāpita apaharita abhilāsita avadhārita avica-

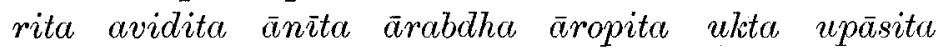
utpādita kathita kārita krta carita cintita chādita jñata tōrnna darśita drsta nimantrita nirmmāpitce niryyātita pūjita prsț pranāmita pratipādita pratilabalha praśamsita prāpta presita bhagnita bhinna bhukta mānita labdha vismärita sruta sanvvarṇita samtarppita saṃtoṣita sambhāsita subhāsita.

(b) The neut.s. with active sense is used with a sing. or plur., masc., neut., or fem. subject. The subject is (i) masc.s. (13), e.g. sa mayâpi darśanam na prāptaṇ Bhagavān, "Bhagavat was not seen by me"; śresthi - pranidhānam krtam, " the guild-president made a vow"; 
once this construction is used with passive sense, sa kenapi avicāritam, " he was not noticed by anyone." The auxiliary abhüt is sometimes added. (ii) Fem.s., e.g. sā patakam - - ksiptam, "she threw the cloth." (iii) Dual, e.g. nàv adya labdham suvisuddha caksuh, "to-day have we two gained sight" ; luśalavihīnau - - annam na prāptam, "bereft of merit they did not obtain food." (iv) Masc.p. (4), e.g. te - samtartum a rabdham, " they began to cross"; te bhiksavas tad annam na bhuktam, "the monks did not eat the food." Cf. the use of the neut.s. of the gerundive (3), e.g. buddha bhilsavo yamakālena na bhoktavyam, "Buddhist monks must not eat at the season of Yama." (v) Neut.p., e.g. brāhmanasahasrāni - - srotāpattiphalam $s \bar{a} k s \underline{a} \bar{t}$ krtam, " thousands of brāhmans made manifest the fruit of conversion." It should be noted that of these twenty examples, twelve have an object in the acc. neut.s., four in the acc. masc. or fem. s., while four have no object.

The active participle in -tavat is used passively (6), e.g. Ratnamatītilhy yatavān, "called Ratnamati"; Bhagavān mahat̄̄ satkārena püjitavān, "Bhagavat was honoured with great reverence."

The gerundive in -tavya is active (5), e.g. ye ye tathāgatam arcanābhilāsajanās tasmim mandale 'rcayitavyāh, "whatever people desire to worship the Tathāgata, let them worship in this circle"; tasmäd bhilsavas tathāgatesu kāāapayitavyāh, "therefore, O monks, you must do honour to Tathāgatas."

3. Voice.-Active : (a) for middle in bhăsantam, ramati ramanti ramatah; (b) for passive with the verbs cint darsaya pra-muc vrij, e.g. nīcena mahatã câpi kuladharmman na varjayet, "the family law should not. be transgressed by small or great"; tvaya--cintayati, "it is thought by thee."

Middle: (a) for active in kathayasva śrnudhvam; (b) for passive in the present stem with the verbs

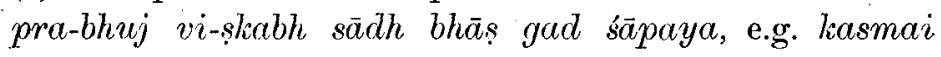


sädhayate dravyan putro vā te na vidyate, "for whom is thy wealth being prepared? thou hast no son"; yena yena krtam karmmam tena tena prableunjate, "by whomsoever a deed is done, by him it is enjoyed."

Passive: for active in the verbs $j \tilde{n} \bar{a}$ (3) ram a $\vec{a}$ ropaya ci, e.g. sukhaduhkham ca sarveșām kathaṇ na jñāyase nrpa, " how dost thou not recognize, O king, the joy and sorrow of all ?"; agaccha ramyāmahe, "come, let us make love."

4. Concord.-(a) A singular subject is followed by a plural verb, e.g. tvatkīrttir yāvat sanisāras tisthati tãvat tistheyuh, " may thy fame extend as far as existence extends." (b) A dual subject is followed by a singular verb, e.g. tasya dvau puträv asti, "he has two sons." (c) A plural subject is followed by a singular verb (7), e.g. $t \bar{\alpha}$ arciso - - antarhito 'bhüt, " the rays were hidden";

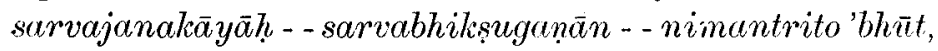
"all the people entertained all the monks."

5. The following causative formations are used in the same sense as the simple verb (33): anuśăsayati abhiprasādayati abhilāsayati avarohayati āhvöyayati uttārayati utpādayati upavāsayati upasamikrāmayati ksobhayati nāśayati nipatayati nipātayati nisksāmayati paripālayati pratinivrttayati pravāyati praśamsayati bhaksayati bhāsayati vikarttayati vidvesayati vismārayati śāpayati śāsayati śosayati sam̧hāorayati.

\section{The Sentence}

Constructions of sense as opposed to the strict rules of grammar are frequent, e.g. Sakrah - - saparivāro - - divam

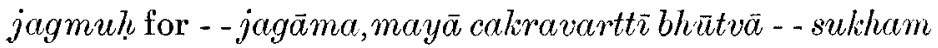
anublūtam for cakravarttina, yad yad abhiprāyam tat. tat tasyai dattāni for dattam.

Two constructions are confused: (a) sa nāvikus tatre sthātum mano na ramate, "the sailor does not wish to remain there" (a confusion of tasya navvikasya - - manal, 
and sa nāvileas--manasi); tatah pratyāgate--kälam gatal, "then when he had returned he died (10). (b) The sentence begins with an indeclinable participle and omits

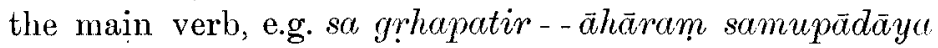
vilepanāni ca\| (c) Active and passive constructions are confused, so that the instrumental appears as the subject of an active verb (5), e.g. lena cid grhasthena - - tîrthikān bhojitah, "a certain householder fed the heretics"; taya cetikaya stuppe puspāny avaropayati, "the maid places the flowers on the stuppa." (d) The reverse of $(c)$ : a nominative takes the place of an instrumental, e.g. Bhagavān dharmmadeśan $\bar{\alpha}$ krtā, " the law was expounded by Bhagavat."

The use of the parenthesis is peculiar (5), e.g. sa ka $\mathrm{alam}$ krvtvä Kauravyarājño mahis̄i tasyāh kukssâv upapannah, "when he died he entered the womb of the wife of the king of the Kauravyas": tatas tasyālpāyuṣkālam krtvā Śrāvastyām mahānagaryyām anyatamadharmmaśīla-

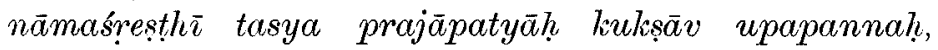
"then dying young he entered the womb of the wife of a guild-president named Dharmmaśila in the great city of Śrāvastī."

\section{VOCABULARY}

In the following lists I have inserted those words also which occur elsewhere only in Northern Buddhist literature or in the lexicographers.

1. Peculiar meanings. adbhuta, n., astonishment. adhikrtya, c.gen., concerning. ananna, no food. abhipsita, desirable. arhati is used impersonally. avakirati, surround. avarohayati, avaropayati, get on to, place on. $\bar{a} k u l a$, n., confusion, crowded place.

$\bar{x} b$ hoga, effort.

àścaryya, n., miracle.

uccheda $=$ ucchinna ; cf. upa-

patti and prabodha.

ujvala, m., light.

ipacāraka, servant.

upapatti $=$ upapanna. 
uparodhaka, destroying.

upekşā, regard.

ullola, n., large wave.

karpața, garment.

kalita, n., roar.

kārayati, rule.

$\bar{k} \bar{a} r \bar{a}$, act of worship.

kuñcita, controlled.

koșthāgära, bedroom.

cintāpara, thought.

janaśunya, n., empty place.

jānapada, country.

jìrnna, n., ruins.

tapa, m., austerity.

täda, drum.

tvakssas, energy.

darśanam präpnoti, be seen.

dadāti, take.

durvāra, irresistible power.

duskrta, infirmity.

dhānya, n., wealth.

dhairya, wise.

na param, but not.

niyata, continuity.

pataka, n., cotton cloth.

paralokavat, of the next

world.

parinivarttate, return.

paryaykam äbhavati, take up

a squatting position.

pìta, n., beverage.

punyatman, m., the state of

being virtuous.

pauruseya, retainer.

prakrti, image.

pratigrhnäti, forgive.

pratibhāna, splendour.

pratisara, daybreak.

prabodha, enlightened. prayāti, give.

prādurbhāva, manifest.

prāñjali, obeisance.

bhīta, n., fear.

manasikära, love.

mithy $\bar{a}$, falsehood.

yati, whatever.

ratnamaya, $\mathrm{n}$., offering of

jewels.

varāhäśva, ? stallion.

vallari, a particular kind of

musical instrument.

vaśi, subjugation.

vāhini, baggage animal.

vivaśa, $\mathrm{n}$., independence.

saranam karoti, seek protection.

samsad, presence.

samgata, n., collection.

sampasyati, make to appear.

sahadharmma, marriage.

sarvath $\bar{a}$, at all times.

sãñali, obeisance.

sāhasam karoti, be excited.

sukhastha, n., feeling of happi-

ness.

sudullabha, very hard to be

imitated.

surabhi, perfume.

sauhärda, n., friend.

styāna, n., sloth.

svastha, m., health.

2. Peculiar words.

akuksa, past child-bearing.

agnimatha, m. or n., stove.

acetani, adj.f., delirious.

ajānaka, ? infant.

atiklesita, very sinful.

atitrs $\bar{a}$, great thirst. 
atiprasādayati, be very joyful. atyadhikam, very much. atyabhirüpa, very beautiful. atyāścaryya, very wonderful. adhivāsana, ? pertinacity. adhyāsaya, having at heart. adhyāsayati, rule. aniñjamāna, unmoving. apadakșaya, n., purification. apaharitā, the state of being carried away. apratisama, incomparable. $a \bar{b} \bar{a} d h a t \bar{\alpha}$, freedom from annoy ance. abhinivesana, $\mathrm{n}$., the act of dwelling.

$a b h i p r a b h \bar{a}$, splendour. abhibodhana, enlightenment. alpäyutva, short life. avadhiryyatha, 2 p. imp. act., have courage ; ? dhīra. asaktatva, lack of power. $\bar{a} k s \bar{l} l i t a$, washed. agarjita, puffed up. adikam, to begin with. $\bar{a} p a$, quantity of water. ärägayati, love. $\bar{a}$ varnnana $\bar{a}$, description. $\bar{a}$ svastha , illness. kaśmìraśżla, ? saffron. $k \bar{a}$ mamithyã, incest. kārttikapürnnamāsi, f., name of a month.

kusththavista, leprosy. krsnāparājita, name of a plant. ksayatva, n., destruction. $k s a u d r a$, n., honey. khañjaka, limping. gudagudāyate, rumble. grddha, vulture.

jämbuinadākșa, name of a flower. taripanya, $\mathrm{n}$, ferry money.

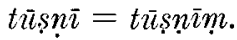

tripradakșina, n., three pradakșinas.

tripradakșinitkaroti, make the three $p r a^{\circ}$. durbaudha, foolish.

dvārībhavati, be at the door. dhātvāvaropana $=$ dhātvava. nityaśah, always. nirnnașta, destroyed. nispamsaka, free from everything contemptible. nispratikāra $=$ nisprati ${ }^{\circ}$. pratipraśrabdha, ? converted. prabhakṣati, feed.

prādeśikamandalin, ruler of a district. prābhinandati, rejoice. prāvișkaroti, make manifest. balasth $\bar{a}$, strength.

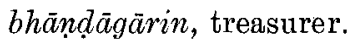
$b h \bar{\imath} t \bar{a}$, fear. mandalinarājan, chieftain of a small district. mahānāgĩvisa, a particularkind of snake.

mahānuśamsāa, verses in praise of a particular virtue, usually at the end of an avādana. māsi, f., month. yatha $=$ yatha. yoniśah, thoroughly. rātryātyayāt $=$ rātryaty ${ }^{\circ}$. 
vanija, merchant.

Vapușmadāvadāna $=$ Vapuss . madava ${ }^{\circ}$.

viti $=$ viti.

vidyuttana, lightning.

virāgayati, dislike.

vişada, dejection.

vihela, wantonness.

veśmatā, dwelling. samādara, great reverence.

sampariganayati, consider.

sampratibodhiki, enlightening.

samprativārana, protection

against.

sambuddhatva, n., perfect

Buddhahood.

sambubhuksita, hungry.

sustukara, good fortune. 